\title{
El pobre y el rico, mundos opuestos
}

\section{Juana Griselda García}

LaRevolución mexicana fue un movimiento que se llevó a cabo en 1910 en México. E1 movimiento revolucionario fue una catarsis del pueblo entre clases sociales por un gobierno dictador y autoritario que fue el de Porfirio Díaz. La Revolución mexicana fue uno de los temas de inspiración del director y actor "El indio" Fernández y del fotógrafo Gabriel Figueroa. Ellos hicieron un gran equipo para crear su propia perspectiva en el cine mexicano a través de sus propios ojos y sentimientos sobre la lucha de un pueblo para conseguir su libertad y la tierra prometida. Los mexicanos dieron su vida y su alma en la Revolución, y es justo mencionar que la gente que luchó incansablemente se convirtió en la tierra, en el polvo que descansa en los encantados y mágicos paisajes mexicanos, heredándonos el México moderno de hoy.

Fernández-Figueroa a través de la película Flor Silvestre (1943), encarnan una historia romántica que muestra crudamente las diferencias sociales tan marcadas, donde la mirada del indígena campesino se levantaba humildemente para mirar al cacique como el todopoderoso. El acertado close-up del rostro perfecto de "Esperanza", la humilde muchacha comparada con una flor silvestre, que por el simple hecho de haber crecido en el campo y no en el selecto jardín de la hacienda, el rico hacendado no la valoraba porque la consideraba pobre e inferior. Esta historia muestra también la cara de la muerte, la única compañera de camino de los campesinos indígenas. La muerte era lo único seguro que llevaban, muestra la violación de la pureza de la Revolución mexicana a través del vandalismo, donde saqueadores y villanos con el estandarte de la Revolución, robaban y asesinaban para beneficio propio. Muestra también el papel de la iglesia católica como consuelo del espíritu humillado y menospreciado, siendo la iglesia el único digno mediador de comunicación entre dos mundos diferentes, entre dos polos opuestos, entre lo blanco y lo negro; el del rico y el del pobre.

También Fernández-Figueroa llenan la pantalla con mágicos paisajes donde tuvieron la influencia de los pintores José Guadalupe Posada, Gerardo Murillo “Dr. Atl”, José María Velazco, David Alfaro Siqueiros y el muralista Diego Rivera. En la película, mostraron los paisajes encantados, con una perspectiva oblicua, como sacados de un cuento mágico. Ellos matizaron el nopal como símbolo tradicional mexicano y de identidad. El nopal, que continuaba vivo y firme, cuyas lágrimas no eran visibles sino las guardaba dentro de él. Perfecta representación de los indios campesinos, callados, abnegados y sufriendo las inclemencias del tiempo. En este caso, el tiempo de la opresión. El gobierno de Don Porfirio Díaz es representado en la 
película por Don Francisco Castro, el hacendado rico. También padre de José Luis, un próspero y autoritario hacendado, que llegó a golpear a su hijo José Luis por desobedecerlo al casarse con Esperanza, a quien humilla y ofende por considerarla de poco valor para su hijo. El hacendado rico es la perfecta representación de un gobierno injusto para los pobres, para los humildes y para el pueblo mexicano. Un gobierno que buscaba prosperidad, bonanza y desarrollo económico. Un gobierno que abrazaba la bandera de la ironía. Ante los ojos del mundo, el gobierno de Porfirio Díaz mostraba a un México próspero y rico. Sólo que la prosperidad y la riqueza eran los derechos destinados únicamente para los ricos privilegiados, mientras que el pueblo pobre abrazaba la auténtica bandera tricolor: el verde de la esperanza de tener un pedazo de tierra, el blanco de la pureza de la Revolución y el rojo de la sangre derramada como símbolo del costo que debían de pagar por anhelar un pedacito de su México y querer escapar del hambre y la represión.

Fernández-Figueroa representaron también, por medio del hijo rico, José Luis, a Francisco I. Madero, el "hijo desobediente" de la burguesía. Francisco I. Madero en la Revolución y José Luis en la película, empatizaban con el pueblo oprimido de querer una igualdad social y que se les diera a los campesinos indígenas la oportunidad, como seres humanos, a lo que por naturaleza les pertenecía, la tierra y libertad. Tenían la esperanza de ver realizados sus sueños, el sueño de la igualdad y la equidad y el sueño de verse como hermanos mexicanos. José Luis fue asesinado por un traidor de la Revolución, Rogelio Torres, y Francisco I. Madero por un traidor de la patria, Victoriano Huerta. El cuerpo de Don Francisco I. Madero, la tierra lo recibió con honor, y la libertad lo llevó a cada uno de los corazones de sus hermanos los mexicanos. Él está presente en la historia que ha sido aprendida de generación en generación, y vivirá en los corazones de sus hermanos los mexicanos.

En conclusión, la Revolución mexicana fue un movimiento revolucionario de un pueblo que explotó en contra del gobierno opresor de Porfirio Díaz, y se originó en el año de 1910. La Revolución mexicana fue uno de los temas de inspiración del actor y director "El indio" Fernández y del fotógrafo Gabriel Figueroa. En la película de romance Flor Silvestre, ellos plasman las diferencias muy marcadas en las clases sociales de la época, el pobre y el rico. El nopal como símbolo de identidad, la iglesia católica como mediadora y consoladora del pueblo afligido y los espectaculares paisajes casi sacados de los cuadros de grandes pintores donde se proyecta un México mágico y tradicional. Un pueblo con la perspectiva de tener la tierra y libertad. 